\title{
MONITORING AND EVALUATION OF THE NATIONAL HEALTH INSURANCE PARTICIPATION IN SURAKARTA, CENTRAL JAVA
}

\author{
Arief Suryono \\ Faculty of Law, Sebelas Maret University
}

\begin{abstract}
Background: Based on 1945 Constitution, the Indonesian government has the obligation to assure that every citizen gets constitutional right of health services. The government is obliged to establish an integrated health system and management under the National Social Security (Jaminan Sosial Nasional, JSN) program. The National Social Security program in health care is implemented in the National Health Insurance program (Jaminan Kesehatan Nasional, JKN). The $\mathrm{JKN}$ is administered by the Implementing Body of Social Security in Health (Badan Penyelenggara Jaminan Sosial Kesehatan, BPJS). Participation in the National Health Insurance is mandatory for all Indonesian citizens and foreigners who have stayed in Indonesia for at least 6 months. The JKN participants consist of premium assistance beneficiaries (PBI) and non-premiun assistance beneficiaries (non-PBI). The JKN started in January 1, 2014 and continues to register new participants by January 1, 2019. Data from BPJS Surakarta showed that by July 2017 the number of registered JKN participants was 448,812 (80.33\%) out of the total population of 558,698. There are 109.886 people have yet to be registered as JKN participants. This study aimed to describe the current status of JKN participation coverage and to provide solution to the implementation of JKN in Surakarta.
\end{abstract}

Subjects and Method: This was a normative legal study with statute approach. This study was conducted in Surakarta, Central Java. The sources of secondary data included legislation, legal document, court decision, law review, legal records, and literature pertinent to law. Primary data were used to complement so as to sharpen analysis.

Results: Participant coverage has been realized by socialization, visit, telemarketing, and supervision. Participation coverage has also been increased by circulating registration letters, enacting local regulation, and developing donation program. The main obstacles of JKN implementation included: (1) Unregistered enterprises; (2) Low number of individual participants; (3) Sub-optimal dropbox registration. The suggested solutions to the obstacles are as follows: (1) Supervision; (2) Re-registration; (3) Socialization; (4) Human resource development forum; (5) Registration by mobile BPJS; (6) Development of JKN cadres; (7) Centralized data; (8) New registration outlets; (9) Colaboration with village heads and trade office.

Conclusion: Approximately 20\% of population in Surakarta have yet to be registered in JKN. Some measures are suggested to increase JKN participation (1) Socialization; (2) Education to the public on the importance of JKN.

Keywords: National Health Insurance, monitoring, evaluation, participation

Correspondence: Arief Suryono. Faculty of Law, Sebelas Maret University, Jl. Ir. Sutami 36 A, Surakarta 57126, Central Java, Indonesia.

Email: arsur15@yahoo.co.id 